thin vine. European readers may not like the use of the term " turtles" for all Chelonia. Surely if " crocodilians" is all right for all Crocodilia the "chelonians" would be better than "turtles", a term which, on this side of the Atlantic, definitely excludes tortoises.

Animal Babies. By Susciitzky. Thames and Hudson. 10s. $6 d$.

The name Suschitzky in animal photography is sufficient to guarantee first-class quality and these sixty-seven pictures, all reproduced in photogravure, are some of his best and most appealing. With the exception of three bird portraits, all are of mammals and they range from elephants, through Rhesus monkeys, to kittens and guinea-pigs. All are of captive or tame animals, and the majority were taken in zoos.

Suschitzky has an eye for a picture and these photographs show what comes from patient waiting, but many people would have been glad to have the technical details of each shot and perhaps a page or so about his general methods. The letterpress is confined to a two-page Introduction.

G. C.

\title{
Wild und Wildschutzgebiete Westafrikas. By G. Dennler de la Tour.
}

This privately published volume in German is apparently the first attempt yet made to assess and compare the efforts towards game preservation in those African countries that border the Atlantic Ocean. Much work has gone into it, and the result is as accurate as the sources of information available to the author. Several regional maps show that scarcely any territory concerned is without its reserves or sanctuaries, but Dr. Dennler de la Tour obviously has to depend on official accounts for much of his material and it is hard not to infer that wild life reserves in some territories are little other than book entries.

It would appear that much is done in the French territories, while the failure of areas under British control to take effective netion is all too well known. (This applies, of course, only to 
West African territories and not to those in the east.) With the increase in self-government international opinion will expect something useful to be done. The survey stops short of South Africa, though a short note by a correspondent sketches the position there and shows that few other countries have done as much. The last quarter of the book lists the majority of species known to occur in the region. Inevitably a book like this has some passages less accurate than others, but we should be thankful to the author for assembling such a volume of useful facts.

G. C.

NOTE.-The above book, price $£ 1$ 10s., may be obtained from the following : Asociación Cultural Natura, Passje Scaver 1656, Buenos Aires, Argentina; I.S. Booksellers, 1 Church Square, Cape Town, S. Africa; John Meinert (Pty.) Ltd., Windhock, S.W. Africa. 